\title{
Preparation and Characterization of $\mathrm{Bi}$ substituted gadolinium iron garnet $\mathrm{Bi}_{x} \mathrm{Gd}_{3-x} \mathrm{Fe}_{5} \mathrm{O}_{12}$ films with $x=1$ to 2.5 by Enhanced Metal Organic Decomposition method
}

\author{
D. A. Wahid, J. Sato, M. Hosoda, and H. Shimizu \\ Department of Electronic and Information Engineering, Tokyo University of Agriculture and Technology, 2-24-16 Naka-cho, \\ Koganei-shi, Tokyo 184-8588, Japan
}

\begin{abstract}
Bismuth substituted gadolinium iron garnet thin films $\left(\mathrm{Bi}_{x} \mathrm{Gd}_{3-x} \mathrm{Fe}_{5} \mathrm{O}_{12}\right)$ were prepared with $x=1,2$, and 2.5 on glass substrates by enhanced metal organic decomposition (EMOD) method. We mixed the solution containing $\mathrm{Fe}_{2} \mathrm{O}_{3}$, $\mathrm{Bi}_{2} \mathrm{O}_{3}$ and $\mathrm{Gd}_{2} \mathrm{O}_{3}$ carboxylates so that we could obtain desired $\mathrm{Bi}$ content $x$. X-ray diffraction (XRD), optical transmittance / reflectivity, and Faraday rotation (FR) were measured for characterizations in order to examine their dependence on annealing temperatures and different amount of Bismuth substitution $(x)$. When $\mathrm{Bi}_{x} \mathrm{Gd}_{3 \cdot x} \mathrm{Fe}_{5} \mathrm{O}_{12}$ thin films were directly prepared on glass substrates, $\mathrm{Bi}_{2} \mathrm{O}_{3}$ phase were observed by XRD measurements and with increasing Bi content $x$ from 1 to 2, the FR increased from 1.2 to 5.8 deg./ $/ \mu$ at the wavelength of $530 \mathrm{~nm}$. FR of $\mathrm{Bi}_{2.5} \mathrm{Gd}_{0.5} \mathrm{Fe}_{5} \mathrm{O}_{12}$ thin films prepared directly on glass substrates were smaller $(0.35 \mathrm{deg} . / \mu \mathrm{m})$ than those with $x=2$. When $\mathrm{Bi}_{2.5} \mathrm{Gd}_{0.5} \mathrm{Fe}_{5} \mathrm{O}_{12}$ thin films were prepared with annealing temperature of $620^{\circ} \mathrm{C}$ with $\mathrm{Gd}_{3} \mathrm{Fe}_{5} \mathrm{O}_{12}$ buffer layer on glass substrates, the films showed garnet crystal structure and FR, which is comparable with that of $\mathrm{Bi}_{2.5} \mathrm{Gd}_{0.5} \mathrm{Fe}_{5} \mathrm{O}_{12}$ thin films prepared on (111) (GdCa) ${ }_{3}(\mathrm{GaMgZr})_{5} \mathrm{O}_{12}(\mathrm{SGGG})$ single crystal substrates. These results demonstrate that $\mathrm{Bi}_{x} \mathrm{Gd}_{3-}{ }_{-} \mathrm{Fe}_{5} \mathrm{O}_{12}$ thin films can be prepared on glass substrates with controlled $\mathrm{Bi}$ content and that $\mathrm{FR}$ as high as that prepared on the SGGG substrate can be obtained by the EMOD method.
\end{abstract}

Key words: magnetic garnet, enhanced metal organic decomposition method, Faraday effect.

\section{Introduction}

Bismuth substituted rare-earth iron garnets have a considerable interest owing to their large magneto optic effect. Large FR with high transparency in the visible to near infrared range $^{1)}$ are key properties which made the magnetic garnet materials suitable for various applications for magneto-optical device elements such as in magnetoplasmonic structure ${ }^{2}$, optical isolators ${ }^{3)}$, circulators ${ }^{4,5}$, and magnet photonic crystals (MPCs) used in magneto-optic spatial light modulators (MOSLM) $)^{6-9)}$.

Bismuth substituted gadolinium iron garnet (Bi:GdIG) is a ferrimagnetic material and shows perpendicular magnetic anisotropy, which is one of the most desirable materials for magneto optical devices owing to its high optical transmittance and extremely high magneto optical activity in the visible and near infrared regions ${ }^{10,11)}$, which enable this material to have high frequency application. FR can be controlled by Bi substitution of Gd. Therefore, it is very important to control the amount of $\mathrm{Bi}$ substitution in order to control and increase the FR. There are several methods to prepare the bismuth substituted rare-earth iron garnet thin films such as a laser ablation ${ }^{12)}$, a liquid phase epitaxy $^{13)}$, RF magnetron sputtering ${ }^{14)}$, etc. Among them, metal organic decomposition (MOD) method is a promising one to prepare magnetic garnet film, because it is a simple fabrication method which is composed of spin coating of the MOD solution and annealing, and guarantees high uniformity in chemical composition and purity combined with chemical stability. It was reported that $\mathrm{Bi}_{x} \mathrm{Gd}_{3 \cdot{ }_{x}} \mathrm{Fe}_{5} \mathrm{O}_{12}, \mathrm{Bi}_{x} \mathrm{Y}_{3 \cdot x} \mathrm{Fe}_{5} \mathrm{O}_{12}$, and $\mathrm{Bi}_{x} \mathrm{Y}_{3 \cdot x}(\mathrm{FeGa})_{5} \mathrm{O}_{12}$ thin films were prepared on gadolinium gallium garnet (GGG) ${ }^{12-17)}$ and glass substrates ${ }^{18)}$. We have prepared Bi:GdIG thin films on GGG substrates by annealing with and without $\mathrm{O}_{2}$ gas and investigated the crystal growth process and magnetic anisotropy ${ }^{19}$ ). The fabrication of magnetic garnet such as $\mathrm{Bi}_{2.5} \mathrm{Y}_{0.5} \mathrm{Fe}_{5} \mathrm{O}_{12}$ films was reported by using $\mathrm{Nd}_{2} \mathrm{Bi}_{1} \mathrm{Fe}_{4} \mathrm{Ga}_{1} \mathrm{O}_{12}$ buffer layers on glass substrate which was fabricated by the MOD method, and FR of $13.8 \mathrm{deg} . / \mu \mathrm{m}$ at $\lambda=520 \mathrm{~nm}$ was reported for the $\mathrm{Bi}_{2.5} \mathrm{Y}_{0.5} \mathrm{Fe}_{5} \mathrm{O}_{12}$ films ${ }^{18)}$. It is important to obtain $\mathrm{Bi}_{x} \mathrm{Gd}_{3 \times} \mathrm{Fe}_{5} \mathrm{O}_{12}$ thin films having higher $\mathrm{Bi}$ content $x$ and FR. However, it is reported that preparation of $\mathrm{Bi}_{x} \mathrm{Gd}_{3-x} \mathrm{Fe}_{5} \mathrm{O}_{12}$ with high $\mathrm{Bi}$ content on glass substrates is difficult ${ }^{12-17)}$. Therefore, fabrication of $\mathrm{Bi}_{x} \mathrm{Gd}_{3} \times \mathrm{Fe}_{5} \mathrm{O}_{12}$ thin films with various Bi content $x$ and characterization of FR are important. In order to investigate the effect of changing the Bi content $x$ on FR of $\mathrm{Bi}_{x} \mathrm{Gd}_{3 \times x} \mathrm{Fe}_{5} \mathrm{O}_{12}$ thin films by increasing the $\mathrm{Bi}$ content $x$ systematically, we fabricated the $\mathrm{Bi}_{x} \mathrm{Gd}_{3}{ }_{3} \mathrm{Fe}_{5} \mathrm{O}_{12}$ thin 
films on glass substrates by the EMOD method. Furthermore, we used the $\mathrm{Gd}_{3} \mathrm{Fe}_{5} \mathrm{O}_{12}$ buffer layer in order to fabricate the $\mathrm{Bi}_{x} \mathrm{Gd}_{3{ }_{3}} \mathrm{Fe}_{5} \mathrm{O}_{12}$ thin films with higher $x$ of 2.5 showing larger FR by the EMOD method.

\section{Experiments}

We fabricated $\mathrm{Bi}_{x} \mathrm{Gd}_{3 \cdot{ }_{x}} \mathrm{Fe}_{5} \mathrm{O}_{12}$ thin films with $x=1,2$ and 2.5 at different annealing temperatures of $620^{\circ} \mathrm{C}$, $650^{\circ} \mathrm{C}$ and $700^{\circ} \mathrm{C}$ on $15 \mathrm{~mm} \times 15 \mathrm{~mm}$ glass substrate, and $\mathrm{Bi}_{x} \mathrm{Gd}_{3{ }^{-}} \mathrm{Fe}_{5} \mathrm{O}_{12}$ thin film with $x=2.5$ on $12 \mathrm{~mm} \times 12$ mm SGGG (111) single crystal substrate and $\mathrm{Gd}_{3} \mathrm{Fe}_{5} \mathrm{O}_{12}$ buffer layer / glass substrate by the EMOD method. The EMOD liquids used in this experiment are SYM-FE05 containing $\mathrm{Fe}_{2} \mathrm{O}_{3}$ carboxylates, SYM-BI05 containing $\mathrm{Bi}_{2} \mathrm{O}_{3}$ carboxylates, and SYM-GD01 containing $\mathrm{Gd}_{2} \mathrm{O}_{3}$ carboxylates by Kojundo Chemical Laboratory so that we could obtain $\mathrm{Bi}_{x} \mathrm{Gd}_{3{ }_{x}} \mathrm{Fe}_{5} \mathrm{O}_{12}$ thin films with desired Bi content $x$. Kojundo Chemical Laboratory Ltd provides their own MOD solutions, as well as EMOD solutions developed by Symetrix corporation of the United States and Kojundo Chemical Laboratory Ltd ${ }^{20}$. The MOD solution contains $2-3$ kinds of metal oxides carboxylates such as $\mathrm{Bi}_{2} \mathrm{O}_{3}, \mathrm{Gd}_{2} \mathrm{O}_{3}$, and $\mathrm{Fe}_{2} \mathrm{O}_{3}$ carboxylates in acetic ester to prepare $\mathrm{Bi}_{x} \mathrm{Gd}_{3{ }_{x}} \mathrm{Fe}_{5} \mathrm{O}_{12}$ thin films. In case of preparation of $\mathrm{Bi}_{x} \mathrm{Gd}_{3}{ }_{-} \mathrm{Fe}_{5} \mathrm{O}_{12}$ thin films by the MOD method, Bi content $x$ is fixed. On the other hand, the EMOD solution contains one metal oxide carboxylate in xylene and can be mixed with other EMOD solutions containing other metal oxide. Therefore it is possible to prepare the $\mathrm{Bi}_{x} \mathrm{Gd}_{3{ }^{-}} \mathrm{Fe}_{5} \mathrm{O}_{12}$ thin films in any proportion of $\mathrm{Bi}$ content $x$, which enables greater degree of freedom and more precise control of composition in order to prepare $\mathrm{Bi}_{x} \mathrm{Gd}_{3-x} \mathrm{Fe}_{5} \mathrm{O}_{12}$ thin films. When we prepare the $\mathrm{Bi}_{x} \mathrm{Gd}_{3-x} \mathrm{Fe}_{5} \mathrm{O}_{12}$ thin films with different Bi content $x$ by the EMOD method, the EMOD solutions of $\mathrm{Fe}_{2} \mathrm{O}_{3}$ carboxylate (product name SYM-FE05), $\mathrm{Bi}_{2} \mathrm{O}_{3}$ carboxylate (product name SYM-BI05), and $\mathrm{Gd}_{2} \mathrm{O}_{3}$ carboxylate (product name SYM-GD05), are mixed and combined for different $\mathrm{Bi}$ content $x$, which is advantage compared with the MOD method. The selected components were mixed in the

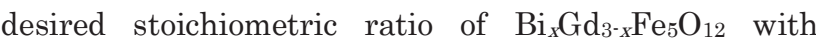
different value of $x=1,2$ and 2.5 and stirred well. The solution was then filtered by advantec filter paper. The solution was spin-coated in 2 steps process of $500 \mathrm{rpm}$ for $10 \mathrm{~s}$ and $2000 \mathrm{rpm}$ for $20 \mathrm{~s}$, followed by drying on a hot plate at $120^{\circ} \mathrm{C}$ for $10 \mathrm{~min}$ and the solvent are evaporated. In order to decompose the organic materials and obtain the amorphous metal oxide films, the samples were pre-annealed at $550^{\circ} \mathrm{C}$ for $10 \mathrm{~min}$. The thickness by single spin coating step is typically 20 - 30 $\mathrm{nm}$. The conditions for spin coating, drying, and pre-annealing were fixed. We changed the mixing ratio of the SYM-BI05 and SYM-GD01 solutions in order to change the $\mathrm{Bi}$ substitution $x$ in $\mathrm{Bi}_{x} \mathrm{Gd}_{3}{ }_{3} \mathrm{Fe}_{5} \mathrm{O}_{12}$ thin films, and changed the final-annealing temperature. The thickness of the samples slightly changes with the spin coating speed, time and viscosity of the solutions. Spin coating, drying and pre-annealing were repeated for 11 times to obtain an appropriate thickness. Spin coating, drying and pre-annealing, were repeated 6 times for the $\mathrm{Bi}_{x} \mathrm{Gd}_{3{ }_{x}} \mathrm{Fe}_{5} \mathrm{O}_{12}$ films on the $\mathrm{Gd}_{3} \mathrm{Fe}_{5} \mathrm{O}_{12}$ buffer layer / glass substrate. Also, we prepared a $\mathrm{Bi}_{x} \mathrm{Gd}_{3-x} \mathrm{Fe}_{5} \mathrm{O}_{12}$ film on SGGG (111) single crystal substrate for a reference sample to compare the FR. The amorphous $\mathrm{Bi}_{x} \mathrm{Gd}_{3-x} \mathrm{Fe}_{5} \mathrm{O}_{12}$ films prepared by pre-annealing process were then annealed at 620,650 and $700{ }^{\circ} \mathrm{C}$ for 2 hours for crystallization (final annealing). The pressure during the annealing was atmospheric pressure. Bi:GdIG thin films prepared in this study were characterized by x-ray diffraction (XRD), optical transmittance, optical reflectivity, and FR spectra. All the measurement was done at room temperature. We measured the XRD from the central part of the samples. The diameter $d$ of the $\mathrm{x}$-ray beam is about $0.4 \mathrm{~mm}$. Therefore, the measurement results of the XRD show average crystallinity of the samples over $d=0.4 \mathrm{~mm}$. We estimated the thickness of the samples from the optical reflectivity spectra, and discussed the relationship between XRD and FR spectra.

\section{Results and Discussion}

Figure 1 shows the optical reflectivity spectra (wavelength $\lambda=250-2600 \mathrm{~nm}$ ) of the $\mathrm{Bi}_{x} \mathrm{Gd}_{3}{ }_{x} \mathrm{Fe}_{5} \mathrm{O}_{12}$ samples annealed at 620,650 and $700{ }^{\circ} \mathrm{C}$, with the $\mathrm{Bi}$ content $x=0,1,2$ and 2.5 on glass substrates. The incident direction of the light was normal to the sample. In order to estimate the thickness of the $\mathrm{Bi}_{x} \mathrm{Gd}_{3{ }^{-}} \mathrm{Fe}_{5} \mathrm{O}_{12}$ films, we fitted the measured optical reflectivity spectra to reproduce the experimental results by the calculated reflectivity spectra. We calculated the reflectivity spectra by considering the multiple reflection inside the $\mathrm{Bi}_{x} \mathrm{Gd}_{3-x} \mathrm{Fe}_{5} \mathrm{O}_{12}$ films by interfaces between air / film (af) and film / glass substrate (fs). We assumed that the film thickness is uniform and the glass substrate is non-absorbing and incoherent material. The reflectivity $R$ is calculated by the following formula (1) ${ }^{21,22)}$. 


$$
\mathrm{R}=R_{a f s}+\frac{R_{s a}\left(T_{a f s}\right)^{2}}{1-\mathrm{R}_{s a} \mathrm{R}_{s f a}}
$$

where $R_{\text {afs, }}$ is the reflectivity within the interface between air (a), film (f), and the interface between film (f) and substrate ( $\mathrm{s}$, $\mathrm{R}_{\mathrm{sfa}}$ is the reflectivity within the interface between substrate (s), film (f), and the interface between film (f) and air (a), and $T_{\mathrm{afs}}$ is the transmission within the interface between air (a), film (f), and the interface between film (f) and substrate (s). $R_{\mathrm{afs}}$, $R_{\text {sfa }}$ and $T_{\text {afs }}$ include the effect of multiple reflections inside the film and can be expressed by the following formulas (2), (3) and (4). They are related to the film thickness $d$, wavelength $\lambda$, and refractive index $n$ - i $k$ of the film. Since the refractive index has wavelength dependence, we divided the optical reflectivity spectra to two regions $(\lambda<1000 \mathrm{~nm}$ and $\lambda>1000 \mathrm{~nm})$, and changed the refractive index and thickness to reproduce the experimentally obtained optical transmission spectra ${ }^{23)}$. In the final stage of the fitting, the films thickness $d$ is obtained.

$$
\begin{gathered}
R_{a f s}=\frac{R_{a f}-\left(2 R_{a f} R_{f s}-R_{f s}\right) e^{-\frac{4 \pi}{\lambda}(n-i k) d}}{1-\mathrm{R}_{a f} \mathrm{R}_{f s} e^{-\frac{4 \pi}{\lambda}(n-i k) d}} \\
T_{a f s}=\frac{\left(1-R_{a f}\right)\left(1-R_{f s}\right) e^{-\frac{2 \pi}{\lambda}(n-i k) d}}{1-\mathrm{R}_{a f} \mathrm{R}_{f s} e^{-\frac{4 \pi}{\lambda}(n-i k) d}} \\
R_{s f a}=\frac{R_{f s}-\left(2 R_{a f} R_{f s}-R_{a f}\right) e^{-\frac{4 \pi}{\lambda}(n-i k) d}}{1-\mathrm{R}_{a f} \mathrm{R}_{f s} e^{-\frac{4 \pi}{\lambda}(n-i k) d}}
\end{gathered}
$$

The simulated reflectivity spectra showed by the dotted lines in figure 1 . The thicknesses were estimated to $170-210 \mathrm{~nm}$ for the samples with $x=1,200-260 \mathrm{~nm}$ for the samples with $x=2$, and $330-360 \mathrm{~nm}$ for the samples with $x=2.5$. The viscosity of the solution was increased with increasing the $\mathrm{Bi}$ content $x$. Therefore the film thickness increased with increasing the $\mathrm{Bi}$ content $x$.

Figure 2 shows the XRD spectra of the fabricated samples on glass substrates. The XRD spectra of samples shows some peaks associated with (420) plane

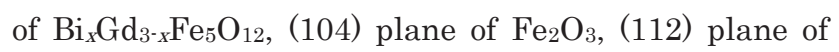
$\mathrm{Gd}_{2} \mathrm{O}_{3}$, (008) plane of $\varepsilon-\mathrm{Bi}_{2} \mathrm{O}_{3}$, (200) plane of $\mathrm{BiO}_{3}$, (222) plane of $\beta-\mathrm{Fe}_{2} \mathrm{O}_{3}$, and (130) plane of $\varepsilon-\mathrm{Fe}_{2} \mathrm{O}_{3}$ phases.

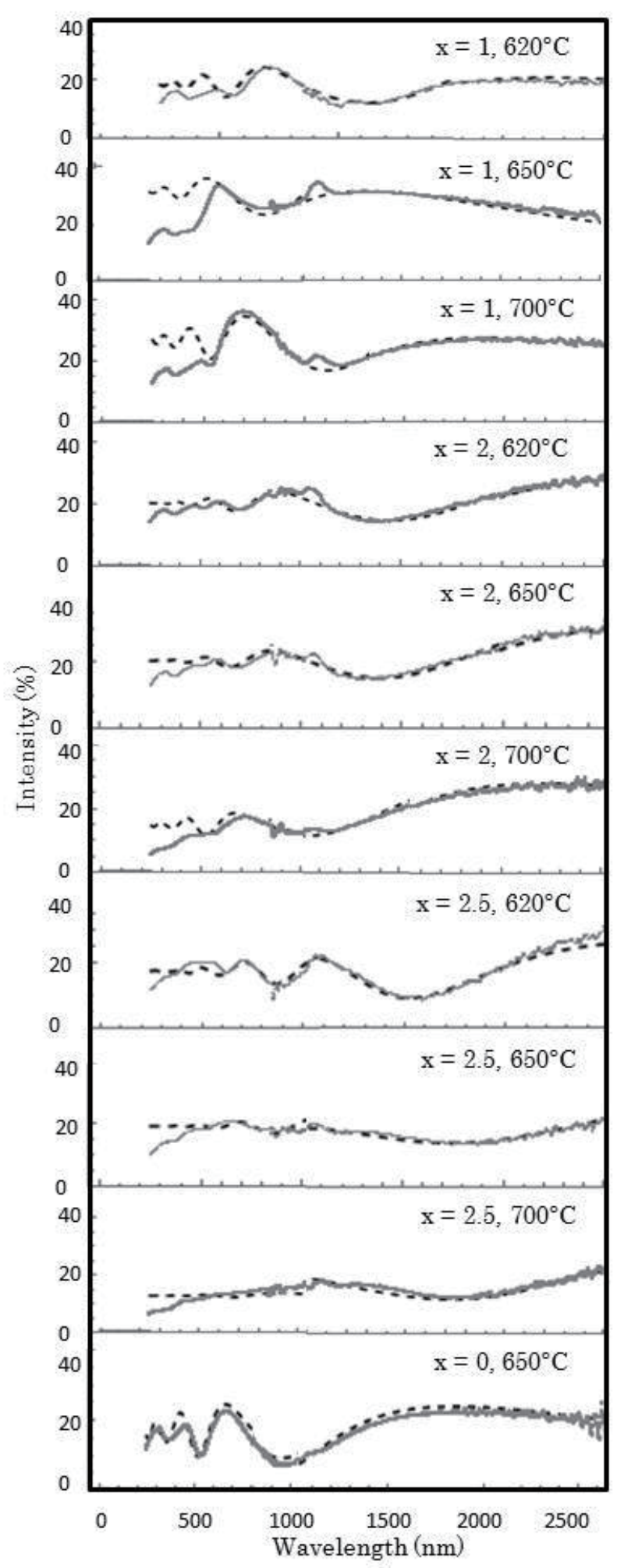

Fig. 1 Optical reflectivity spectra (solid lines) of the $\mathrm{Bi}_{x} \mathrm{Gd}_{3{ }_{x}} \mathrm{Fe}_{5} \mathrm{O}_{12}$ samples annealed at 620, 650 and $700{ }^{\circ} \mathrm{C}$, with bismuth content $x=0,1,2$ and 2.5 on glass substrates. The fitted spectra are shown by dashed lines. 


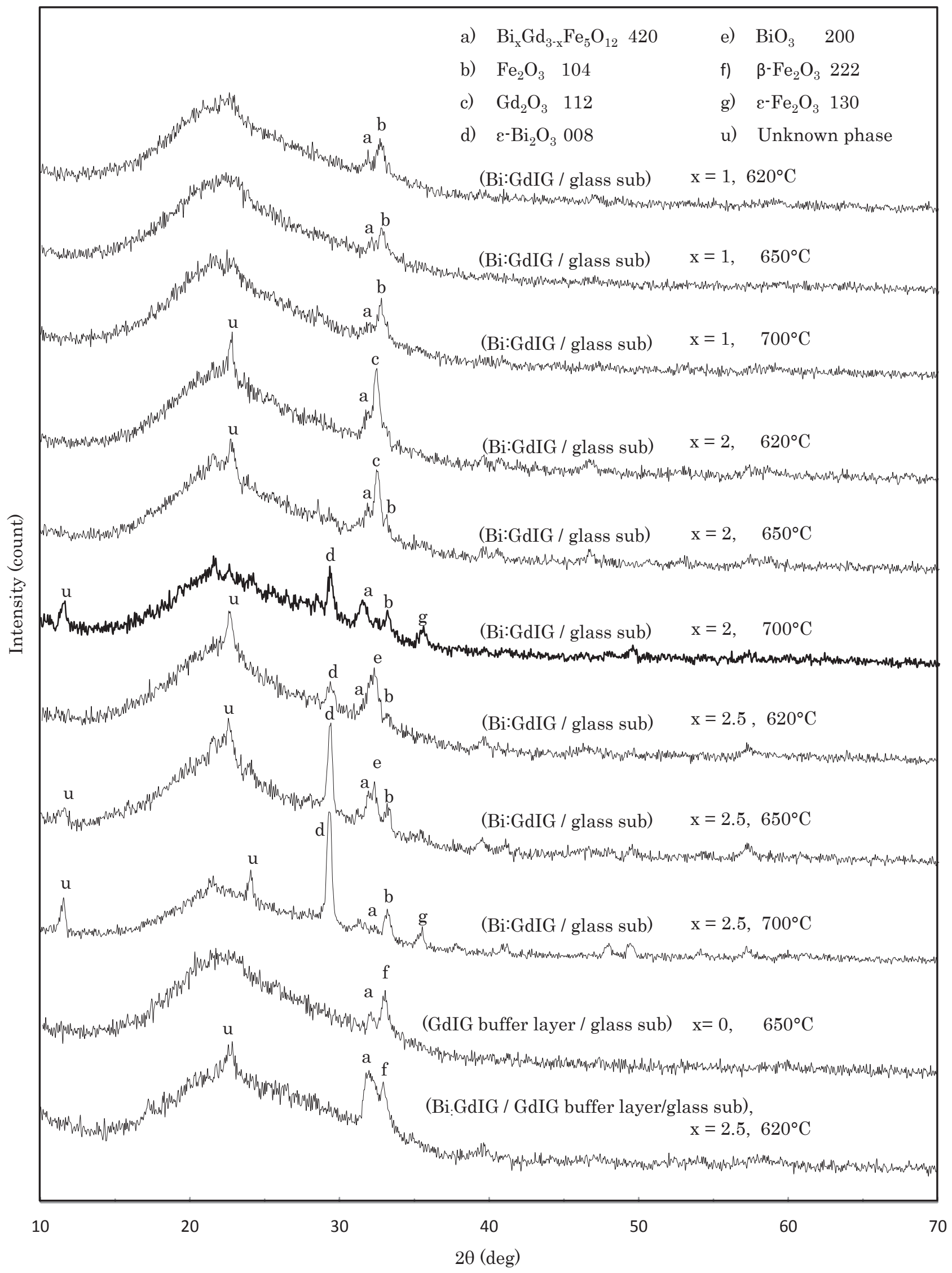

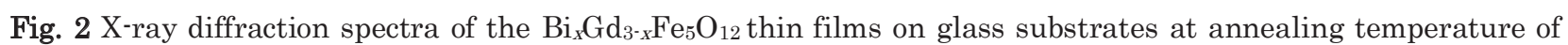
620,650 and $700^{\circ} \mathrm{C}$ with Bismuth doped $x=0,1,2$ and 2.5 on glass substrates and Bi 2.5 :GdIG on GdIG buffer layer/glass substrate. 


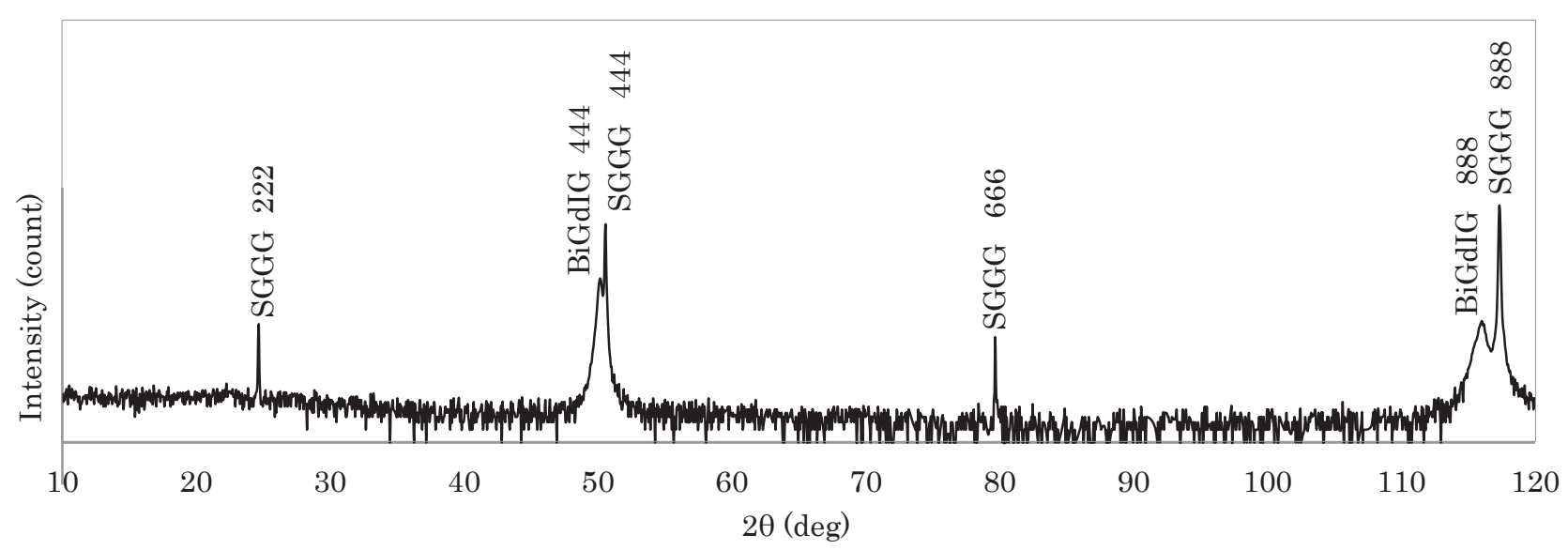

Fig. 3 X-ray diffraction spectra of the $\mathrm{Bi}_{2.5} \mathrm{Gd}_{0.5} \mathrm{Fe}_{5} \mathrm{O}_{12}$ thin film on SGGG (111) single crystal substrate at the annealing temperature of $620^{\circ} \mathrm{C}$. Please note that the vertical axis is in logarithmic scale.

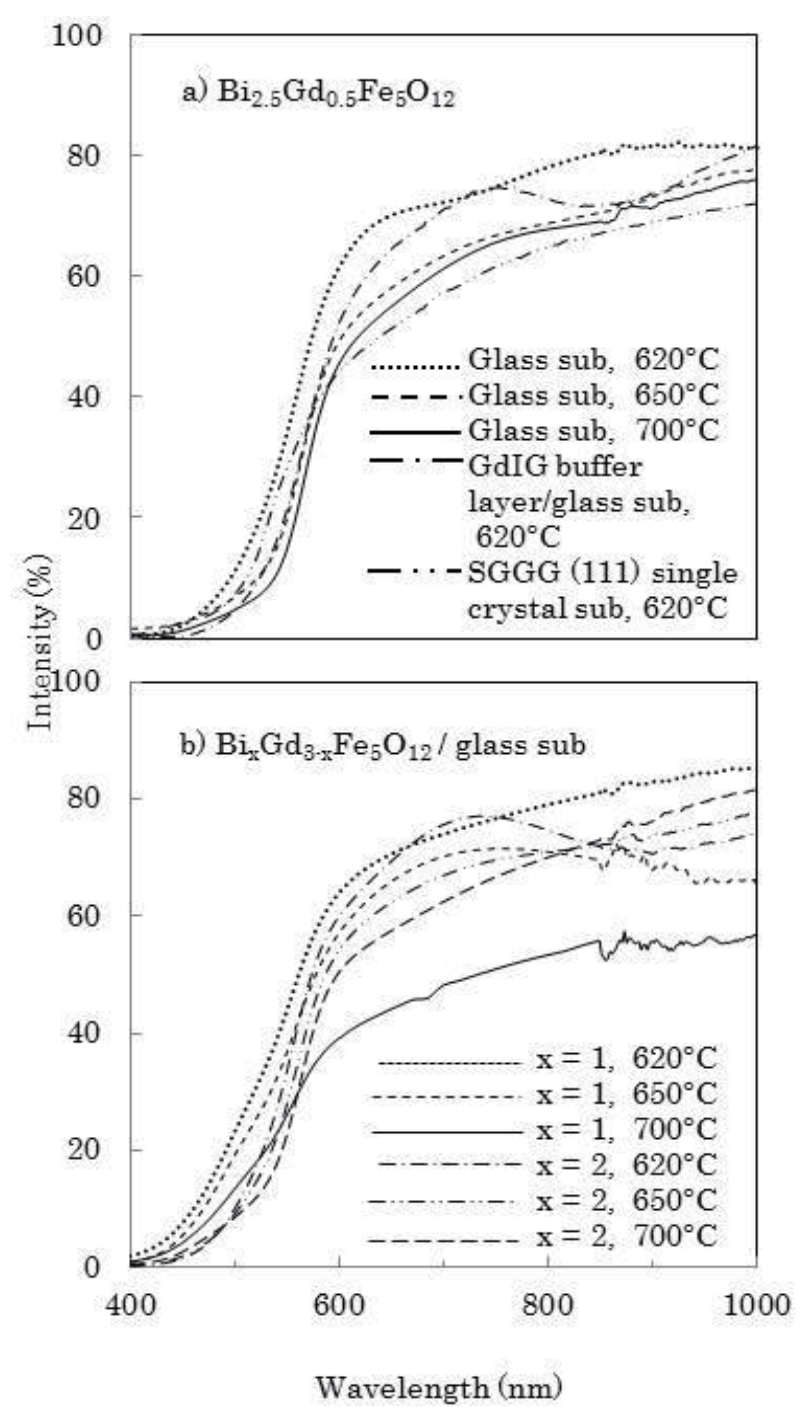

Fig. 4 Optical transmittance spectra of the Bi:GdIG samples annealed at 620,650 and $700{ }^{\circ} \mathrm{C}$, with the bismuth content of a) $x=2.5$ on glass, GdIG buffer layer / glass and SGGG (111) single crystal substrates, b) $x=1$ and 2 on glass substrates.
When the $\mathrm{Bi}_{2} \mathrm{O}_{3}, \mathrm{Gd}_{2} \mathrm{O}_{3}$ and $\mathrm{Fe}_{2} \mathrm{O}_{3}$ carboxylates are mixed with a ratio of $1: 2: 5$, and the annealing temperature of $620-700{ }^{\circ} \mathrm{C}$ directly prepared on the glass substrates, the diffraction signal from $\mathrm{Fe}_{2} \mathrm{O}_{3}$ is larger than that from $\mathrm{Bi}_{x} \mathrm{Gd}_{3{ }_{x}} \mathrm{Fe}_{5} \mathrm{O}_{12}$. When the $\mathrm{Bi}_{2} \mathrm{O}_{3}$, $\mathrm{Gd}_{2} \mathrm{O}_{3}$ and $\mathrm{Fe}_{2} \mathrm{O}_{3}$ carboxylates are mixed with a ratio of $2: 1: 5$ and the annealing temperature of $620-650{ }^{\circ} \mathrm{C}$ directly prepared on the glass substrates, the diffraction signal from $\mathrm{Gd}_{2} \mathrm{O}_{3}$ is larger than that from $\mathrm{Bi}_{x} \mathrm{Gd}_{3}$ ${ }_{x} \mathrm{Fe}_{5} \mathrm{O}_{12}$. When the annealing temperature is $700{ }^{\circ} \mathrm{C}$, the diffraction signal from $\mathrm{Bi}_{2} \mathrm{O}_{3}$ is increased. When the $\mathrm{Bi}_{2} \mathrm{O}_{3}, \mathrm{Gd}_{2} \mathrm{O}_{3}$ and $\mathrm{Fe}_{2} \mathrm{O}_{3}$ carboxylates are mixed with a ratio of $2.5: 0.5: 5$ and the annealing temperature of $620-700{ }^{\circ} \mathrm{C}$ directly prepared on glass substrates, the diffraction signals from $\mathrm{Bi}_{2} \mathrm{O}_{3}$ and $\varepsilon-\mathrm{Bi}_{2} \mathrm{O}_{3}$ are much more dominant than that from $\mathrm{Bi}_{x} \mathrm{Gd}_{3}{ }_{x} \mathrm{Fe}_{5} \mathrm{O}_{12}$. The diffraction peak associated with $\mathrm{Bi}_{x} \mathrm{Gd}_{3{ }_{3}} \mathrm{Fe}_{5} \mathrm{O}_{12}$ were the weakest with $x=2.5$ among all the samples without the $\mathrm{Gd}_{3} \mathrm{Fe}_{5} \mathrm{O}_{12}$ buffer layer. With increasing the final annealing temperature, the diffraction peak associated with $\varepsilon-\mathrm{Bi}_{2} \mathrm{O}_{3}$ increased. From the XRD spectra of the samples, it is difficult to fabricate Bi:GdIG thin films with high Bi content $x=2.5$ directly on glass substrate. In order to solve this problem, we fabricated a gadolinium iron garnet (GdIG) thin film with composition of $\left(\mathrm{Gd}_{2} \mathrm{O}_{3}: \mathrm{Fe}_{2} \mathrm{O}_{3}=3: 5\right)$ as a buffer layer for preparation of $\mathrm{Bi}_{x} \mathrm{Gd}_{3-} \mathrm{Fe}_{5} \mathrm{O}_{12}$ thin films with higher $\mathrm{Bi}$ content $x$ of 2.5, with the thickness of $150 \mathrm{~nm}$ on the glass substrate at final annealing temperature of $650^{\circ} \mathrm{C}$ by the EMOD method. When the $\mathrm{Gd}_{2} \mathrm{O}_{3}$ and $\mathrm{Fe}_{2} \mathrm{O}_{3}$ carboxylates are mixed with a ratio of $3: 5$, the diffraction signals from $\mathrm{Gd}_{3} \mathrm{Fe}_{5} \mathrm{O}_{12}$, and $\beta-\mathrm{Fe}_{2} \mathrm{O}_{3}$ are dominant. 

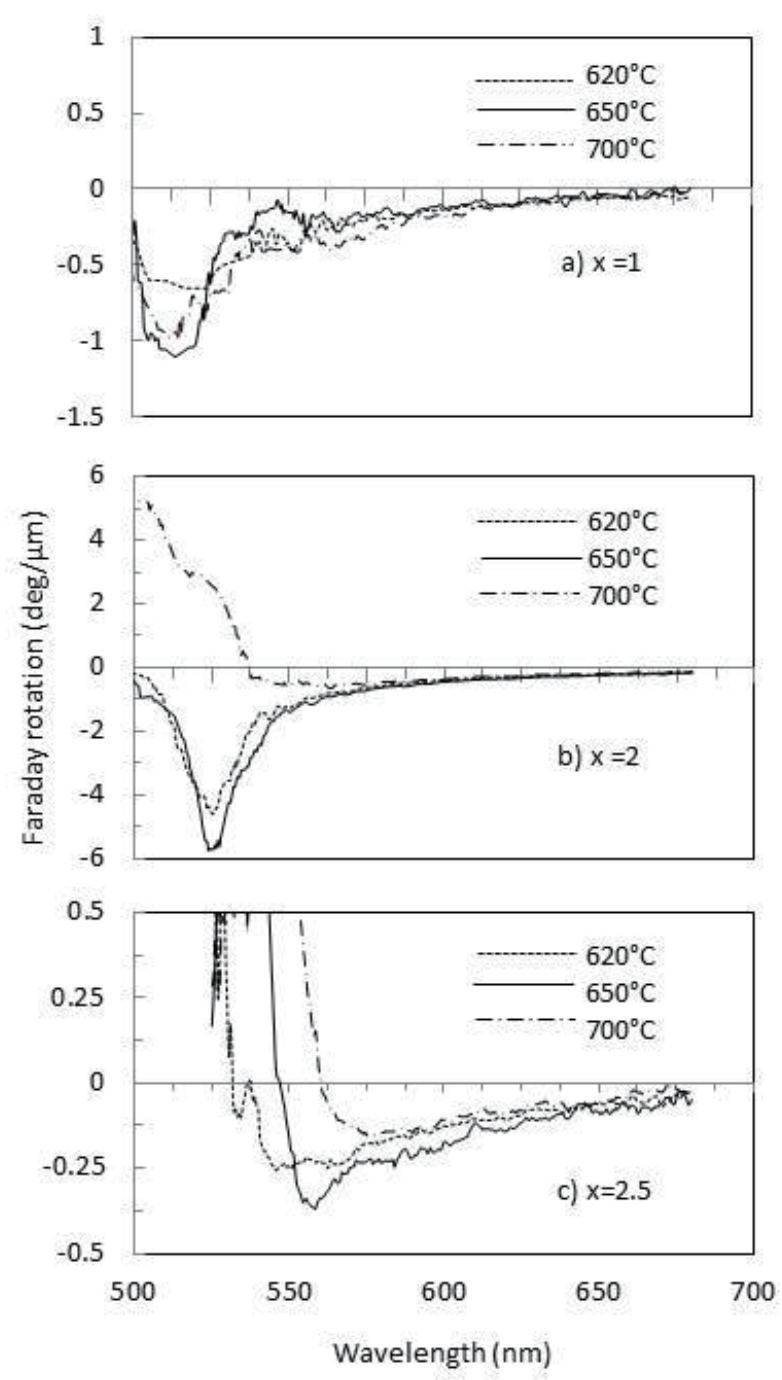

Fig. 5 Faraday rotation spectra of the $\mathrm{Bi}_{x} \mathrm{Gd}_{3}{ }_{x} \mathrm{Fe}_{5} \mathrm{O}_{12}$ samples with different annealing temperatures and bismuth content(a) $x=1$, (b) $x=2$ and (c) $x=2.5$.

Then we tried to fabricate a $\mathrm{Bi}_{2.5} \mathrm{Gd}_{0.5} \mathrm{Fe}_{5} \mathrm{O}_{12}$ thin film on the GdIG buffer layer / glass substrate. The final annealing temperature for $\mathrm{Bi}_{2.5} \mathrm{Gd}_{0.5} \mathrm{Fe}_{5} \mathrm{O}_{12}$ thin film was set at $620^{\circ} \mathrm{C}$ instead of the annealing temperature of $650^{\circ} \mathrm{C}$ shown in figure 2 . This is because when the final annealing temperature of the $\mathrm{Bi}_{2.5} \mathrm{Gd}_{0.5} \mathrm{Fe}_{5} \mathrm{O}_{12}$ film is the same or higher than the final annealing temperature for the GdIG buffer layer/glass sub., the part of crystal structure of the GdIG buffer layer can be destroyed $^{25)}$. Therefore, we set the final annealing temperature at $620^{\circ} \mathrm{C}$ for the $\mathrm{Bi}_{2.5} \mathrm{Gd}_{0.5} \mathrm{Fe}_{5} \mathrm{O}_{12}$ film on the GdIG buffer layer/glass sub.

When the $\mathrm{Bi}_{2} \mathrm{O}_{3}, \mathrm{Gd}_{2} \mathrm{O}_{3}$ and $\mathrm{Fe}_{2} \mathrm{O}_{3}$ carboxylates are mixed with a ratio of $2.5: 0.5: 5$ and the annealing temperature of $620{ }^{\circ} \mathrm{C}$ with the $\mathrm{Gd}_{3} \mathrm{Fe}_{5} \mathrm{O}_{12}$ buffer layer on glass substrate, the diffraction signal from $\mathrm{Bi}_{x} \mathrm{Gd}_{3}$ ${ }_{x} \mathrm{Fe}_{5} \mathrm{O}_{12}$ is the most dominant and the formation of other

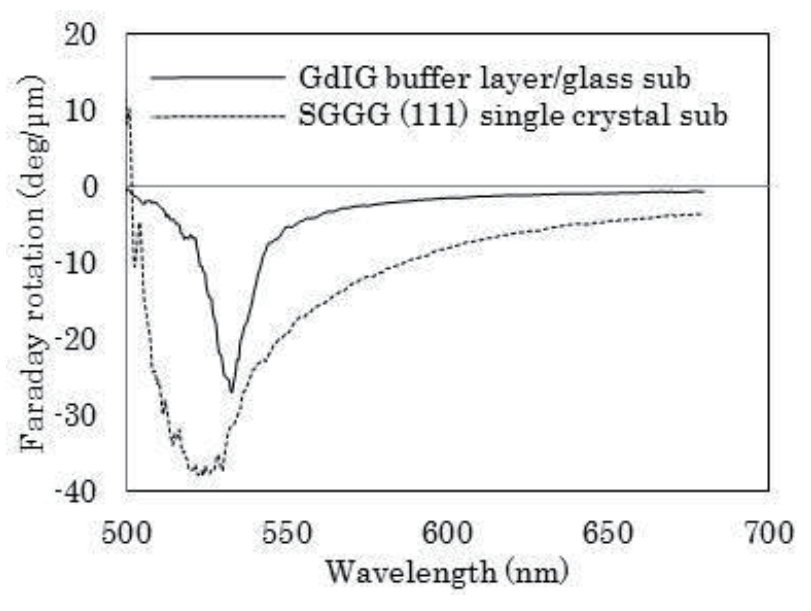

Fig. 6 Faraday rotation spectra of the $\mathrm{Bi}_{2.5} \mathrm{Gdd}_{0.5} \mathrm{Fe}_{5} \mathrm{O}_{12}$ samples annealed at $620^{\circ} \mathrm{C}$ with the bismuth content $x=2.5$ on gadolinium iron garnet buffer layer / glass sub and SGGG (111) single crystal substrates.

phases such as $\varepsilon-\mathrm{Bi}_{2} \mathrm{O}_{3}, \mathrm{BiO}_{3}$ and $\mathrm{Gd}_{2} \mathrm{O}_{3}$ are suppressed. The diffraction peak associated with $8-\mathrm{Fe}_{2} \mathrm{O}_{3}$ at the right side of the $\mathrm{Bi}$ :GdIG diffraction peak is associated with the $\mathrm{Gd}_{3} \mathrm{Fe}_{5} \mathrm{O}_{12}$ buffer layer. From figure 2, it was confirmed that the $\mathrm{Bi}_{2.5} \mathrm{Gd}_{0.5}-\mathrm{Fe}_{5} \mathrm{O}_{12}$ thin film having garnet crystal structure was prepared with the buffer layer on glass substrate by the EMOD method.

Figure 3 shows the XRD spectra of $\mathrm{Bi}_{2.5} \mathrm{Gd}_{0.5} \mathrm{Fe}_{5} \mathrm{O}_{12}$ prepared by the EMOD method on (111) SGGG single crystal substrate. 444 and 888 diffraction peaks are clearly observed and other peaks associated with polycrystalline or impurity phases were not observed. The lattice constant a was calculated to $1.2587 \mathrm{~nm}$. It was reported that the lattice constant of $\mathrm{Bi}_{2.5} \mathrm{Gd}_{0.5} \mathrm{Fe}_{5} \mathrm{O}_{12}$ samples prepared by liquid phase epitaxy (LPE) was $1.259 \mathrm{~nm}^{24)}$, and comparable to that of our $\mathrm{Bi}_{2.5} \mathrm{Gd}_{0.5} \mathrm{Fe}_{5} \mathrm{O}_{12}$ thins films on (111) SGGG substrate. By comparing the lattice constant of two materials and the results of figure 3 , we estimated the composition of our single crystal film to $\mathrm{Bi}_{2.5} \mathrm{Gd}_{0.5} \mathrm{Fe}_{5} \mathrm{O}_{12}$ by the EMOD method. Also the diffraction peaks associated with $\mathrm{Bi}_{2} \mathrm{O}_{3}, \quad \mathrm{Gd}_{2} \mathrm{O}_{3}, \quad \mathrm{Fe}_{2} \mathrm{O}_{3}, \quad \mathrm{GdIG}$ and $\mathrm{BiGdIG}$ of the polycrystalline samples on the glass substrates were confirmed by comparing the lattice spacing $d$ measured by the XRD to the powder diffraction files of international center for diffraction data (ICDD). Therefore, we estimated the fabricated crystal structure by the EMOD method to the garnet structure.

Figure 4 shows the optical transmittance spectra of the $\mathrm{Bi}_{x} \mathrm{Gd}_{3}{ }_{x} \mathrm{Fe}_{5} \mathrm{O}_{12}$ thin films on the glass substrates with / without $\mathrm{Gd}_{3} \mathrm{Fe}_{5} \mathrm{O}_{12}$ buffer layer and on (111) 
SGGG single crystal substrate. The $\mathrm{Bi}_{2.5} \mathrm{Gd}_{0.5} \mathrm{Fe}_{5} \mathrm{O}_{12}$ on the $\mathrm{Gd}_{3} \mathrm{Fe}_{5} \mathrm{O}_{12}$ buffer / glass sub has high transparency in visible and near infrared region, higher than the $\mathrm{Bi}_{2.5} \mathrm{Gd}_{0.5} \mathrm{Fe}_{5} \mathrm{O}_{12}$ film on (111) SGGG substrate.

Figure 5 shows the FR spectra of the fabricated $\mathrm{Bi}_{x} \mathrm{Gd}_{3{ }_{x}} \mathrm{Fe}_{5} \mathrm{O}_{12}$ thin films crystallized at 620, 650, and $700{ }^{\circ} \mathrm{C}$ with $x=1,2$ and 2.5 on glass substrates. The magnetic field of $1 \mathrm{~T}$ was applied perpendicular to the samples in order to fully magnetize the samples.

The samples with the annealing temperature of $650^{\circ} \mathrm{C}$ show larger $\mathrm{FR}$ (negative) than the other samples with $x=1,2$, and 2.5 annealed at 620 and $700{ }^{\circ} \mathrm{C}$. Therefore the annealing temperature of $650^{\circ} \mathrm{C}$ is the optimum condition for crystallization of the BiGdIG thin films on the glass substrate by the EMOD method. The FR of Bi:GdIG increased with increasing $x$ to 2, and decreased in the sample with high Bi content of $x=2.5$.

Figure 6 shows the FR spectra of the $\mathrm{Bi}_{2.5} \mathrm{Gdd}_{0.5} \mathrm{Fe}_{5} \mathrm{O}_{12}$ thin films on the GdIG buffer layer / glass substrate and SGGG (111) single crystal substrate. $\mathrm{Bi}_{2.5} \mathrm{Gd}_{0.5} \mathrm{Fe}_{5} \mathrm{O}_{12}$ thin film on the GdIG buffer layer / glass substrate showed $27.5 \mathrm{deg} . / \mu \mathrm{m}$ at the wavelength of $533 \mathrm{~nm}$, which is 8 times larger than that without the GdIG buffer layer. This is because the sample with the GdIG buffer layer showed the largest diffraction signal from the $\mathrm{Bi}_{x} \mathrm{Gd}_{3{ }_{x}} \mathrm{Fe}_{5} \mathrm{O}_{12}$ and garnet structure, and the samples without garnet structure including other phases such as $\mathrm{Bi}_{2} \mathrm{O}_{3}$ and $\mathrm{Gd}_{2} \mathrm{O}_{3}$ showing little $\mathrm{FR}$, as shown in figure 2.

Maximum FR (negative) angle of the $\mathrm{Bi}_{2.5} \mathrm{Gd}_{0.5} \mathrm{Fe}_{5} \mathrm{O}_{12}$ thin films on SGGG substrate is $32.5 \mathrm{deg} . / \mu \mathrm{m}$ at the wavelength of $533 \mathrm{~nm}$. The maximum FR of the $\mathrm{Bi}_{2.5} \mathrm{Gd}_{0.5} \mathrm{Fe}_{5} \mathrm{O}_{12}$ thin films on the GdIG buffer layer / glass substrate is comparable with that on (111) SGGG single crystal substrate. The $\mathrm{FR}$ of $\mathrm{Bi}_{2.5} \mathrm{Gd}_{0.5} \mathrm{Fe}_{5} \mathrm{O}_{12}$ thin films on the $\mathrm{Gd}_{3} \mathrm{Fe}_{5} \mathrm{O}_{12}$ buffer layer / on glass substrate ( $27.5 \mathrm{deg} . / \mu \mathrm{m}$ at $\lambda=533 \mathrm{~nm}$ ) is 3 time larger than that of the reported $\mathrm{Bi}_{1.4} \mathrm{Gd}_{1.6} \mathrm{Fe}_{5} \mathrm{O}_{12}$ sample $(9.3 \mathrm{deg} . / \mu \mathrm{m}$ at $\lambda=520 \mathrm{~nm}$.), which was fabricated by sintering, hot press and annealing method ${ }^{26)}$. Also it was reported that $\mathrm{Bi}_{2.5} \mathrm{Gd}_{0.5} \mathrm{Fe}_{5} \mathrm{O}_{12}$ films on $\mathrm{Nd}_{2} \mathrm{Bi}_{1} \mathrm{Fe}_{4} \mathrm{Ga}_{1} \mathrm{O}_{12}$ buffer layers on a glass substrate which was fabricated by the MOD method had FR of 13.8 deg./ $\mu \mathrm{m}$ at $\lambda=520 \mathrm{~nm}$, which is half of the FR of our $\mathrm{Bi}_{2.5} \mathrm{Gd}_{0.5} \mathrm{Fe}_{5} \mathrm{O}_{12}$ thin films on the $\mathrm{Gd}_{3} \mathrm{Fe}_{5} \mathrm{O}_{12}$ buffer layer / on glass substrate ${ }^{18)}$. Therefore, our samples fabricated by the EMOD method showed 2 3 times larger FR compared with that of previously reported $\mathrm{Bi}_{x} \mathrm{Gd}_{3-\mathrm{x}} \mathrm{Fe}_{5} \mathrm{O}_{12}$ samples.

\section{Conclusion}

We have prepared $\mathrm{Bi}_{x} \mathrm{Gd}_{3{ }_{x}} \mathrm{Fe}_{5} \mathrm{O}_{12}$ thin films on glass substrates, with and without $\mathrm{Gd}_{3} \mathrm{Fe}_{5} \mathrm{O}_{12}$ buffer layer prepared on glass substrates and (111) SGGG single crystal substrate by the EMOD method. We characterized the XRD, FR and optical transmittance spectra of the samples. The FR shows that the annealing temperature of $650{ }^{\circ} \mathrm{C}$ is the optimum condition for crystallization of $\mathrm{Bi}_{x} \mathrm{Gd}_{3{ }_{3}} \mathrm{Fe}_{5} \mathrm{O}_{12}$ on the glass substrate. From the XRD spectra, the $\mathrm{Bi}_{2.5} \mathrm{Gd}_{0.5} \mathrm{Fe}_{5} \mathrm{O}_{12}$ samples on the $\mathrm{Gd}_{3} \mathrm{Fe}_{5} \mathrm{O}_{12}$ buffer layer shows that the Bi:GdIG thin films were successfully fabricated on the glass substrates without forming $\mathrm{Bi}_{2} \mathrm{O}_{3}$ and $\mathrm{Gd}_{2} \mathrm{O}_{3}$ phases, which are observed in samples without $\mathrm{Gd}_{3} \mathrm{Fe}_{5} \mathrm{O}_{12}$ buffer layer. Furthermore, larger Faraday rotation (27.9 deg./ $\mathrm{mm}$ at $\lambda=533 \mathrm{~nm}$ ) was obtained on the sample with the $\mathrm{Gd}_{3} \mathrm{Fe}_{5} \mathrm{O}_{12}$ buffer layer than that without $\mathrm{Gd}_{3} \mathrm{Fe}_{5} \mathrm{O}_{12}$ buffer layer, and the Faraday rotation is comparable with that prepared on SGGG (111) single crystal substrate. It is important to suppress the formation of the $\mathrm{Bi}_{2} \mathrm{O}_{3}$ and $\mathrm{Gd}_{2} \mathrm{O}_{3}$ phases by the $\mathrm{Gd}_{3} \mathrm{Fe}_{5} \mathrm{O}_{12}$ buffer layer in order to prepare $\mathrm{Bi}_{x} \mathrm{Gd}_{3{ }_{x}} \mathrm{Fe}_{5} \mathrm{O}_{12}$ thin films having higher Bi content $x$ and FR, from the XRD spectra and measurement of the Faraday rotation. These findings are important to realize $\mathrm{Bi}_{x} \mathrm{Gd}_{3-\mathrm{x}} \mathrm{Fe}_{5} \mathrm{O}_{12}$ thin films having large Faraday rotation for future applications to MOSLMs and optical isolators on the glass substrates.

Acknowledgements This work was partially supported by JSPS KAKENHI (Grant Number 24656010 and 15K13942) and Support Center for Advanced Telecommunications (SCAT) Technology Research, Foundation. The authors would like to thank Prof. T. Sameshima for the guidance of the optical reflectivity measurement.

\section{References}

1) P. Hansen, H. Heitmann, and K. Witter: Phys. Rev. B., 23, 6085 (1981).

2) L. Halaga cka, K. Postava, M. Vanwolleghem, F. Vaurette, J. Ben Youssef, B. Dagens, and J. Pǐstora: J. Opt. Soc. Am. A., 4, 1903 (2014).

3) H. Ishikawa, K. Nakajima, K. Machida and A. Tanii: $O p t$ Quantum Electron., 22, 517 (1990).

4) W. Smigaj, L. Magdenko, L. Magdenko, J. Romero, S. Guenneau, B. Dagens, B. Gralak and M. Vanwolleghem: Phot. Nano. Fund. Appl., 10, 83 (2012).

5) W. Smigaj, J. Romero, B. Gralak, L. Magdenk, B. Dagens and M. Vanwolleghem: Opt. Lett., 35, 568 (2010).

6) H. Kato, T. Matsushita, A. Takayama, M. Egawa, H. Uchida, K. Nishimaura, and M. Inoue: Trans. Magn. Soc. Jpn., 4, 289 (2004).

7) H. Takagi, J. Kim, K. H. Chung, S. Mito, H. Umezawa, and 
M. Inoue: J. Magn. Soc. Jpn., 33, 525 (2009).

8) S. Mito, K. Takahashi, F. Kawanishi, K. H. Chung, H. Takagi, J. Kim, P. B. Lim, and M. Inoue: J. Magn. Soc. Jpn., 32, 63 (2008).

9) K. H. Chung, J. Heo, K. Takahashi, S. Mito, H. Takagi, J. Kim, P.B.Lim and M.Inoue: J. Magn. Soc. Jpn., 32, 114 (2008).

10) M. Suzuki, T. Kotani, N. Yamaguchi, T. Miura, M. Yamaoka, M. kobayashi, and A. Misu: J. Electron. Spectrosc. Relat. Phenom., 78, 291 (1996).

11) W. Eppler, and M. H. Kryder: IEEE Trans. Magn., 25, 3743 (1989).

12) M. Laulajainen, P. Paturi, J. Raittila, H. Huhtinen, A.B. Abrahamsen, N.H. Andersen and R. Laiho: J. Magn. Magn. Mater., 279, 218 (2004).

13) J. M. Robertson, S. Wittekoek, Th. J. A. Popma, and P. F. Bongers: Appl. Phys., 2, 219 (1973).

14) Y. H. Kim, J. S. Kim and S. I. Kim: J. Korean Phys. Soc., 43, 400 (2003).

15) T. Ishibashi, A. Mizusawa, N. Togashi, T. Mogi, M. Houchido and K. Sato: J. Cryst. Growth., 275, 2427 (2005).

16) T. Kosaka, M. Naganuma, M. Aoyagi, T. Kobayasi, S. Niratisairak, T. Nomura, and T. Ishibashi: J. Magn. Soc.
Jpn., 35, 194 (2011).

17) T. Ishibashi, A. Mizusawa, N. Togashi, T. Mogi, M. Houchico, and K. Sato: J. Cryst. Growth., 275, 2427 (2005)

18) T. Ishibashi, T. Yoshida, S. Ikehara and T. Nishi: J. Appl. Phys., 113, 17A926 (2013).

19) D. A. Wahid, T. Hattori, J. Sato, and H. Shimizu: J. Magn. Soc. Jpn., 39, 100-106, (2015).

20) http://www.kojundo.co.jp/English/Guide/material/csd.html

21) D. Pekker, and L. Pekker: Thin Solid Films., 425, 203 (2003).

22) M. M. Gader: Euro. Intl. J. Sci. Technol., 2, 214 (2013).

23) R. Kitamura, L. Pilon, and M. Jonasz: Appl. Opt., 46, 8118 (2007).

24) P. Hansen, K. Witter, and W. Tolksdorf: Phys. Rev., 27, 4375 (1983).

25) M. Hosoda, J. Sato, D. A. Wahid, H. Shimizu: Proc. the 63rd. spring meeting of Japan Society of Applied Physics., 20a-S621-2, Tokyo, (2016).

26) H. Takeuchi: Jpn. J. Appl. Phys., 14, 1903 (1975).

Received Jan. 27, 2016; Accepted May. 12, 2016 